\title{
The author's response
}

\author{
Yohei Hirano*, Shunsuke Madokoro, Yutaka Kondo, Ken Okamoto and Hiroshi Tanaka
}

We thank you for your interest in our study which performed systematic review and meta-analysis of randomized controlled trials (RCTs) on the effect of corticosteroid treatment initiated in an early stage of acute respiratory distress syndrome (ARDS) [1]. We are willing to provide our response to address your concerns.

As we described in Additional file 2, the report by Annanne et al., one of the studies included in our meta-analysis, was a post hoc analysis of the RCT [2]. The original RCT targeted on patients with septic shock [3]. Although we included this report in our meta-analysis, it was interpreted with special caution taking its specific population of ARDS into consideration. We excluded the RCT from Liu et al. [4]. As shown in Figure 1, 2 in our article [1], RCTs that were not published in English have been excluded from the screening process of full-text articles in our meta-analysis. Moreover, the inclusion criteria of the RCT by Liu et al. were ARDS patients combined with critical illness-related corticosteroid insufficiency (CIRCI), which obviously exhibits a specific population to assess the effect of corticosteroids. The RCT by Rezk et al. was also excluded due to the different setting of its outcome; while our primary outcome was 28 - or 30 day mortality, they only showed 7- or 14-day mortality in their report.

For the primary outcome in our meta-analysis, the optimal information size (OIS) criteria were met when we set the relative risk reduction at $30 \%$. Thus, we did not consider the imprecision to be "serious."

This reply refers to the comment available at https://doi.org/10.1186/s40560021-00529-9.

* Correspondence: yhirano@juntendo-urayasu.jp

Department of Emergency and Critical Care Medicine, Juntendo University Urayasu Hospital, 2-1-1 Tomioka, Urayasu, Chiba 279-0021, Japan
However, as the recommended setting of relative risk reduction ranges between 20 and $30 \%$, it is possible that someone who set it at $20 \%$ sees higher imprecision risk in it.

We realize that there are still several limitations in our study. The possibility of publication bias was described in the discussion (Limitations of the study) because the reliability of Egger's linear regression test is weak due to the limited number of RCTs covered in it. Although we carefully downgraded the certainty of evidence because it should not be made in the mathematical manner, it is understandable if someone would assess it even lower taking these concerns more seriously.

Nevertheless, we believe that the current metaanalysis would provide valuable information for clinical practitioners to help them decide on early corticosteroid treatment on ARDS. Attention should be paid to the initiated timing of corticosteroids. Although it is true that this treatment still remains controversial and yet to be improved, the current meta-analysis, as well as accumulating evidence on the efficacy of corticosteroid treatment in COVID19 , would accelerate the future invention of betterdesigned trials that might clear uncertainty of the evidence on corticosteroid therapy in ARDS.

\section{Authors' contributions}

The authors read and approved the final manuscript.

\section{Declarations}

Competing interests

The authors declare that they have no competing interests.

Published online: 16 March 2021

References

1. Hirano Y, Madokoro S, Kondo Y, Okamoto K, Tanaka H. Corticosteroid treatment for early acute respiratory distress syndrome: a systematic review and meta-analysis of randomized trials. J Intensive Care. 2020;8:91.

2. Annane D, Sébille $V$, Bellissant E. Effect of low doses of corticosteroids in septic shock patients with or without early acute respiratory distress syndrome. Crit Care Med. 2006;34(1):22-30. 
3. Annane D, Sébille V, Charpentier C, Bollaert P-E, François B, Korach J-M, et al. Effect of treatment with low doses of hydrocortisone and fludrocortisone on mortality in patients with septic shock. JAMA. 2002;288:862-71.

4. Liu L, Li J, Huang YZ, Liu SQ, Yang CS, Guo FM, et al. The effect of stress dose glucocorticoid on patients with acute respiratory distress syndrome combined with critical illness-related corticosteroid insufficiency. Zhonghua Nei Ke Za Zhi. 2012;51:599-603.

\section{Publisher's Note}

Springer Nature remains neutral with regard to jurisdictional claims in published maps and institutional affiliations.

Ready to submit your research? Choose BMC and benefit from:

- fast, convenient online submission

- thorough peer review by experienced researchers in your field

- rapid publication on acceptance

- support for research data, including large and complex data types

- gold Open Access which fosters wider collaboration and increased citations

- maximum visibility for your research: over $100 \mathrm{M}$ website views per year

At $B M C$, research is always in progress.

Learn more biomedcentral.com/submissions 